\title{
THE NATURAL ENVIRONMENT AS A LEARNING SOURCE FOR SCIENCE: IMPLEMENTATION STRATEGY
}

\author{
Widodo Setiyo Wibowo ${ }^{1 *}$, \\ ${ }^{1}$ Study Program of Science Education, Faculty of Mathematics and Natural Sciences, Universitas Negeri Yogyakarta \\ Corresponding Author. Email: widodo_setiyo@uny.ac.id
}

Keywords:
Natural
Environment,
Learning Source,
Science

Keywords:

Natural

Learning Source,

Science

\begin{abstract}
Science is closely related to nature, so the natural environment is one of the most important sources of learning both as means and an object. The particular study aimed to discuss the strategy of using and implementing the natural environment as a learning source for science in junior high schools. The results found out that the use of the natural environment as a learning source for science can be pursued through fieldwork, bringing the environment into the classroom, or also making the school science parks. Using the natural environment as a learning source for science requires careful preparation and planning from the teacher. The learning implementation performed in 3 main stages; preparation, implementation, and follow-up. Through the proper implementation of these stages, various benefits achieved either for students or teachers.
\end{abstract}

C2019 JSER. Yogyakarta State University

\section{INTRODUCTION}

According to Braund and Reiss (2005: 4), learning is an active process related to experience and conducted when someone wants to understand the world. Learning is a change in behavior as a result of the interaction of learners with the environment/experience (Michael \& Modell, 2008: $3)$. To shape experiences about the world around or environment, students must use a variety of relevant learning sources. Learning sources may be in the form of humans, materials, events, settings, techniques that build conditions for students to acquire knowledge, skills, and attitudes (Suparno, 1999: 74). More concisely, NCERT (2005) grouped learning sources into three types, namely objects and phenomena, representations of objects and phenomena, and written descriptions. The diversity of learning resources requires teachers to choose the most appropriate source in the context of learning. Appropriate learning sources will assist teachers in organizing and managing the classroom environment as a learning environment and will increase the level of student participation (Creemers \& Reezigt, 1996; Kyriakides \& Creemeers, 2008).
Each subject in junior high school (SMP) has specific characteristics in its learning, as well as science subjects. Science is an activity to answer and explore the universe and discover new things (Carin, 1993: 4). It also conveyed by Douglas P. Newton (2008: 4), science is a way of thinking and working to understand the world or nature. This indicates that science must be sourced from nature. So, in science, the natural environment must also be the main source of learning. The learning process must emphasize the provision of direct experience to develop competencies to explore and understand the nature around scientifically. Science learning lead towards inquiry and conducting, so that help student to gain a deeper understanding of the natural surroundings (Depdiknas, 2008).

However, some teachers have not optimized the natural environment as a source of meaningful learning and not able to improve the quality of learning outcomes in science learning. Also, some teachers are more likely to give a presentation to material and examples on the board and give assignments. This will certainly minimize the interaction among students and teachers, teaching materials, and also the learning environment; so that learning becomes monotonous (Heneveld \& Craig, 
1995). Whereas learning resources that can be observed, touched, moved; those will motivate students and create an ideal learning climate (Grossinikle, 1983). With the presence of learning sources in front of students, it can provide sensory experiences to facilitate the students into good learning (Bizimana \& Orodho, 2014: 113). It will also shift the science learning habits that only teach students with memorization into meaningful learning activities.

The reasons for teachers when they do not use the natural environment as a learning source are; require high costs and difficult to obtain. However, armed with creativity, teachers can create and provide simple and inexpensive learning sources. Likewise, in using the natural environment as a learning source for science, it does not need to go far and high cost. Moreover, the environment near of schools and homes may use as a source of learning. More clearly, this article discussed the strategy of using and implementing the natural environment as a learning source for science in junior high schools.

\section{METHOD}

The particular research used literature review method. Various concepts related to the natural environment, the nature of learning sources, strategies for implementing the natural environment as a learning source for science, and the benefits were examined using various references to make a comprehensive study from various points of view.

\section{RESULT}

Science deals with how to find out about nature systematically. Therefore, the natural environment is a very important source of learning and has very valuable values in the context of the science learning process. Besides, the natural environment can enrich learning materials and activities. The natural environment in science may interpret as everything that exists in a school or home of students including living things and inanimate objects, such as the schoolyard, open space, park, river, lake, forest, beach, cave, mountains, and atmosphere. Those can be used as a source of learning (Dillon \& Dickie, 2012: 2). The natural environment may use as the object of observation, a means or place to conduct experiments/investigations, and as a place to get information. The natural environment uses to learn the natural phenomena and foster students' awareness of the love of nature and participation in preserving the nature (Basuki, 1993: 39; Coskie et al., 2007).
In accordance with the Content Standards of Curriculum 2013, the scopes of science in SMP / MTs are: (1) facts, concepts, procedures, and metacognitive; (2) scientific work and work safety; (3) living things and living processes (plants, animals and humans); (4) energy and changes; (5) substances and their properties; (6) earth and space; and (7) science, environment, technology and society. Based on the scope of science, the teacher must choose the appropriate components of the environment to use as a learning source for the material of biotic and abiotic. The following are some examples of the use of objects and phenomena in the natural environment as a learning source for science:

a. Environment as a source of learning about living things and life processes, for example:

1) Students can learn about how to plant and care for plants.

2) Students can learn about the Photosynthesis.

3) Students can learn about substances affect the growth of the plant.

4) Students can learn about the diversity of animal in the garden.

5) Students can learn about chlorophyll.

6) Students can learn about the types of plants planted in the garden.

b. The environment as a learning source about substances and their properties, for example:

1) Students can learn about the types of substances through observations on the land, sea, and air.

2) Students can find various abiotic components such as rocks, soil, etc. then analyze them.

3) Students can find out the relationship between other abiotic components and their uses.

c. Environment as a learning source about energy and its changes, for example:

1) Students can find out the source of energy, such as heat energy from the sun, kinetic energy from the wind, electricity from turbines, sound energy and so forth.

2) Students can find out how to use energy and various alternative energies.

3) Students can find out energy changes, for example, from heat energy converted into kinetic energy or vice versa.

d. The environment as a learning source about the earth and space, for example:

1) Students can learn about the shape of the earth and describe it through observations in the neighborhood.

2) Students see the things that can be seen through the earth about celestial objects such as the moon, sun, stars and so on. 
3) Students can learn about changes in the physical environment such as weather and natural disasters (floods, landslides, and hurricanes) and learn how to deal with disasters.

4) Students can observe environmental damage through direct observation such as abrasion, erosion, and pollution.

5) By learning through the environment, learners can find out the kinds of natural resources provided by the environment such as renewable and non-renewable natural resources and their utilization.

Utilization of the natural environment as a learning source can be achieved by fieldwork (Dillon \& Dickie, 2012: 2). Fieldwork is an activity by bringing students into the environment, such as observation, investigation, experiments, surveys, field trips, field practice and so on. Lately, it develops learning activities with the concept of outdoor learning, which is a learning process using nature. Also, the use of the environment can be done by bringing the environment into the classroom, such as bringing objects of nature or presenting speakers to deliver material in the classroom.

To support the use of the natural environment as a learning source for science, can also use school gardens. This area can be planted with plants, fish ponds, or breeding various types of animals so that it becomes a school science park. If the school does not have a large area of the garden, verticulture may become the solution. With science plants in schools, teachers can invite students out of the classroom to learn various science materials, such as the scope of living things and life processes. For example, in the material of diversity, students lead at the various types of plants and they are asked to classify based on the characteristics they can observe. Learning becomes more fun than lecturing or discussions in the classroom, because students can see, hold, and discuss the real object being studied. Learning outside the classroom can improve learning standards and offer direct contact experiences with the natural environment (English Outdoor Council, 2010).

Using the natural environment as a media and learning source for science requires careful preparation and planning from the teacher. Ofsted (2008) notes that if planned and implemented properly, this will contribute significantly to the development of personal, social, and emotional abilities of students. Also, students can develop knowledge and skills in terms of adding value to daily experiences from the class (Rickinson et al., 2014). Without careful planning, the learning activities might not run well. As a result, the objectives are not achieved and students do not perform the expected learning activities. Even (Dillon \& Dickie, 2012: 3) stated that the benefits might be reduced when there is no good preparation, lack of pedagogical skills, and lack of follow-up in the class.

There are several steps in using the natural environment as a learning source for science (Nana Sudjana \& Ahmad Rivai, 2007):

a. Preparation

The steps in preparation are:

1) The teacher determines the indicators and learning objectives that are expected mastered by students.

2) Determine the objects that must be learned or visited and are relevant to the learning objectives.

3) Determine the way of students in learning when interact or visit the object, for example, note the phenomena occur, observe a process, ask questions or interview.

4) Arranging learning tools such as lesson plans, student worksheets (LKPD), modules, and assessment tools.

5) Technical preparations for learning activities, such as the rules at the location of the destination object, a camera to take photos, transportation, costs, food or supplies, and first aid kit.

b. Implementation

Implementation step is to determine the learning activities at the destination in line with the plans.

1) Learning activities begin with observations about the object being studied or visited.

2) Students ask questions based on their observations.

3) All students record all data/information.

4) The students in the group analyze and discuss the data/information.

5) Teachers guide students' discussions to stay in line with the learning goals.

c. Follow-Up

The follow up of learning activities through the natural environment is discussing the observation results during the activity.

1) Each group must report and present the results of the discussions in class. And, the teacher provides clarification and reinforcement of the concepts.

2) Students conclude the material under the guidance of the teacher and ask for impressions obtained by students from the learning activities.

3) The teacher assesses the learning activities of students and the results of achievement. 


\section{CONCLUSION}

The natural environment is a very important source of learning both as a vehicle and an object in science learning. Utilization of the natural environment as a learning source can be achieved by fieldwork, such as observation, investigation, experiments, surveys, field trips, field practice and so on. Also, the use of the environment can be done by bringing the environment into the classroom. Schools can also be school science parks as a learning source. Using the natural environment as a learning source for science requires careful preparation and planning from the teacher to achieve the optimal benefits. In short, the implementation steps consist of 3 main stages; preparation, implementation, and follow-up.

The advantages of using the natural environment as a learning source are (1) making students obtained information based on direct and real experience; (2) making easy for students to achieve the specified learning goals; (3) making students know and love the environment which ultimately admires and glorifies its creator; (4) relatively low cost; (5) $\mathrm{n}$ line with the problems faced in daily life, then the students will feel that learning science is meaningful and interesting; and (6) In line with the principles of didactics and development.

Besides the advantages, the weaknesses of using the natural environment as a learning source for science are (1) students play around; (2) requires extra supervision to regulate students; and (3) takes a long time.

\section{REFERENCES}

Basuki Wibowo (1993). Media Pengajaran. Jakarta: Direktorat Jendral Pendidikan Tinggi.

Bizimana Benjamin \& John Aluko Orodho (2014). Teaching and Learning Resource Availability and Teachers' Effective Classroom Management and Content Delivery in Secondary Schools in Huye District, Rwanda. Journal of Education and Practice, 5(9), 111-122

Braund, $\mathrm{M}$ and Reiss, M. (2005). Learning Science Outside the Classroom. New York: Taylor \& Francis e-Library.

Carin, A. A. (1993). Teaching science through discovery $\left(7^{\text {th }}\right.$ ed). New York: Macmillan.

Coskie, T., Hornof, M. \& Trudel, H. (2007). A natural integration. Quoted from "Understanding the diverse benefits of learning in natural environments" Kings
College London April 2011 available at http://publications.naturalengland.org.uk/f ile/5389125523865600

Depdiknas (2008). Panduan Pengembangan Pembelajaran IPA Terpadu SMP/MTs. Jakarta: Puskur-Balitbang Depdiknas.

Dillon, J. \& Dickie, I. (2012). Learning in the Natural Environment: Review of social and economic benefits and barriers. Natural England Commissioned Reports, Number 092.

English Outdoor Council (2010). Time for change in outdoor education. Randall Williams May 2010 available at https://www.englishoutdoorcouncil.org/w p-content/uploads/Change.pdf

Grossinikle, R. (1983). Discovering Meaning in Elementary School Mathematics (7th Ed.). London: CRS College Publishing House.

Heneveld, W. and Craig, H. (1995). "Schools Count". World Bank Technical Paper" No. 303.

Kementerian Pendidikan dan Kebudayaan (2013). Standar Isi kurikulum 2013. Jakarta: Kemdikbud

Michael, J. A. and Modell, H. I. (2008). Active learning in secondary and college science classrooms: a working model for helping the learner to learn. New Jersey: Taylor \& Francis e-Library.

Nana Sudjana \& Ahmad Rivai. (2007). Media Pengajaran. Bandung: Sinar Baru Algensindo.

NCERT (2005). Development of Context Specific Teaching-Learning Materials. Availableon:http://wikieducator.org/Teac hing_Learning_Material.

Newton D. P. (2008). A practical guide to teaching science in the secondary school. New York: Routledge Taylor \& Francis Group.

Ofsted. (2008). Learning outside the classroom. How far should you go? London: Alexandra House.

Rickinson et al. (2004). The value of outdoor learning: evidence from research in the UK and elsewhere. School Science Review, March 2006, 87(320)

Suhaenah Suparno (1999). Pemanfaatan Pengemb Belajar Pendi Dasar. Jakarta: Depdikbud. 
Widodo Setiyo Wibowo/ JSER 2019, 3(1), 67 